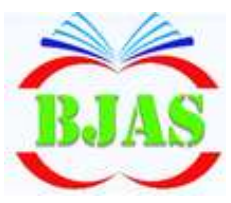

ISSN 1814 - 5868
Available online at http://bjas.bajas.edu.iq

https://doi.org/10.37077/25200860.2021.34.2.10

College of Agriculture, University of Basrah

Basrah J. Agric. Sci. 34(2), 118-132, 2021
Basrah Journal of Agricultural Sciences

E-ISSN: 2520-0860

\title{
Ex-ante and Ex-post Evaluation of Advanced Production System Module in Saffron (Crocus sativus) in India using Consumer Surplus Model and Propensity Score Matching
}

\author{
Masudul H. Wani ${ }^{1}$, Arshad Bhat ${ }^{1 *}$ \& Sajad H. Baba ${ }^{2}$ \\ ${ }^{1}$ Rajiv Gandhi Chair in Contemporary Studies on Livelihood and Food Security, Sher-e- \\ Kashmir University of Agricultural Sciences and Technology of Kashmir, India \\ ${ }^{2}$ Faculty of Fisheries, Division of Social Sciences, Sher-e- Kashmir University of \\ Agricultural Sciences and Technology of Kashmir, India
}

*Corresponding author email: bhatarshad09@gmail.com

Received 24 August 2020; Accepted 23 April 2021; Available online 4 November 2021

\begin{abstract}
A very important breakthrough in saffron cultivation and production was achieved by Sher-e- Kashmir University of Agricultural Sciences and Technology of Kashmir (SKUAST-K) when the university developed a production system module in saffron which brought substantial increase in productivity of saffron during last two decades. The adoption of the technology was observed to have a very significant impact on the social dynamics of the saffron producing region demanding its ex-ante and ex-post evaluation vis a vis non adopters of the technology. With this in mind consumer surplus model and propensity score matching methods were employed on a sample of 447 respondents of which 286 were adopters and 161 non-adopters (control group) drawn from a population of 753 saffron growers in the saffron belt of Jammu and Kashmir producing 99\% of the total saffron production in the country. The results revealed that average productivity of the spice increased from $2.57 \mathrm{~kg} \cdot \mathrm{ha}^{-1}$ to $6.05 \mathrm{~kg} \cdot \mathrm{ha}^{-1}$, with $1-2 \mathrm{~kg} \cdot \mathrm{ha}^{-1}$ in the first year to 10-12 kg.ha ${ }^{-1}$ in fourth year against control group, however, the investment cost estimates recorded increase of $5.9 \%$ under ex-ante and $13.6 \%$ under ex-post evaluation while adopting new technology, which however, got compensated through realizing higher productivity and increased employment to the tune of 40.6 and 28.3 per cent man-days/ha respectively under ex-ante and ex-post evaluation. The results further revealed, NPV, BCR, IRR of Rs. 399 crores, 110, 154\% against Rs.249 crores, 69, 134\% respectively under ex-ante and ex-post evaluation of the technology.
\end{abstract}

Keywords: Productivity, Cultivation, Standard of living, New technology.

\section{Introduction}

The share of Agriculture in the state agricultural gross domestic product (SGDP) decreased from 50 per cent in 1978-79 to 16.0 per cent during 2018-19 (Economic Survey, 2019) in Jammu and Kashmir having 71 per cent rural population mostly depending on agriculture for their sustenance. However, 48 per cent of the agriculture work force contribute only 21 per cent to the SGDP, against 52 per cent of work force engaged in 
non-form activities contributing 79 per cent to the SGDP in 2019, (DoE) thus demanding a re-look into the identification of the potential niche areas with capacities to maintain agroeco system and increasing per unit return of available land resource. Saffron, the costliest spice in the world was cultivated 3-4 centuries before in Arabia and Spain, later spread to Iran, Sweden and India. In India, it is cultivated on an area of 5,707 ha of which more than 66 per cent lies in Kashmir, producing 99 per cent of the total saffron production in the country (UNIDO, 2014). Saffron grown on an area of 3785 hectares producing $13.2 \mathrm{mt}$ (metric tonnes) of saffron is one among various niche crops cultivated in Jammu and Kashmir. The crop experienced a decline in its cultivated area and production from 5707 ha to 3280 ha and $16 \mathrm{mt}$ to $7.70 \mathrm{mt}$ from 1996-97 t0 2008-09 respectively. The decline in production was believed to be due to a long planting cycle of $>15$ years without proper soil health management inviting high incidence of saffron corm rot disease (46\%), damage (10-15 \%) by Rodent Pitymus leucurus supp. (Khalid, 2018) which is diurnal in nature, use of non-graded and low weight corms for fresh plantation coupled with a low lower seed rate/non maintenance of proper plant density. plant $^{-1}$ geometry were probably the main causes that lead to lower saffron productivity $\left(2.5 \mathrm{~kg} \cdot \mathrm{ha}^{-1}\right)$.

Post-harvest handling of saffron, particularly the drying process is critical to the quality of saffron measured by the levels of secondary metabolites viz., Crocin (colour), Picrocrocin (taste) and Safranal (aroma). In addition quick dehydration postharvest treatment is necessary to convert Crocus sativus L., pistil into saffron spice as it prevents bio-degradation of crocin into crocetin which remains a main issue with saffron cultivation in Kashmir Nehvi, et al.
(2018). The new technology in the form of advanced production module was therefore, conceived and pursued through a consistent research effort made by the scientists of the University working on saffron with a predefined goal of achieving higher productivity through addressing the said bottlenecks.

The current study was therefore, undertaken to study the economic feasibility of the new technology by carrying out both ex-ante and ex-post evaluation of the developed production module for devising a pragmatic policy for its development.

\section{Materials \& Methods}

A. A comprehensive survey of the saffron growing areas was undertaken to assess the impact on ground of production system module in saffron developed by the SKUAST-K. The impact of new technology was assessed by taking before and after adoption of new technology module by a group of farmers which group was treated as non-adopters before the adoption of technology to have a rational assessment of new technology. The saffron producing belt is limited to Pampore area where about 5700 ha were put under cultivation of this crop. The whole tehsil Pampore cultivates saffron and have the agricultural land in the same belt. A total number of 447 farmers were selected from among 753 farmers. The information on area, production and yield over various periods of time viz., period-I (1983-85), period-II (1993-95), period-III (2002-04) and period-IV (2011-13), respectively classified as (terrarium) TE-I, TE-II, TE-III and TE-IV, to estimate triennium wise average of area, production and yield, obtained from the published sources of the state and central government. The primary data for ex-ante evaluation was collected directly from the Scientists involved in developing the 
package, while as for ex-post evaluation data was collected through survey method. Published reports by the concerned agency who executed the package in the saffron growing belt were also perused. The average productivity and input costs were estimated from the field data in the saffron belt while the adoption of the package was assessed using economic surplus model which is widely used to assess the impact of technologies owing to its less restrictive assumptions and minimum data requirements. Given the fact that small open economy assumption owing to the tradability of most of the agricultural products and also nonsignificant influence of most of the countries on international prices, we chose to estimate the economic surplus due to yield improvement in a small open economic framework. India being $2^{\text {nd }}$ in the production of saffron in the world and accordingly the $2^{\text {nd }}$ in its export, the benefits accruing out of the adoption of improved technology get normally transacted to the producers.

The economic surplus model was utilized together with the research costs to calculate the net present value (NPV), the internal rate of return (IRR), and the benefit-cost ratio (BCR). This model was used to measure the rate of return to the research under various systems. The aggregate economic impact was assessed considering the rate and time of adoption.

\section{Estimation of Benefit}

$\Delta \mathrm{CS}=\mathrm{P}_{0} \mathrm{Q}_{0} \mathrm{Z}(1+0.5 \mathrm{Z} \eta)$

$\Delta \mathrm{PS}=\mathrm{P}_{0} \mathrm{Q}_{0}(\mathrm{~K}-\mathrm{Z})(1+0.5 \mathrm{Z} \eta)$

$\Delta \mathrm{TS}=\Delta \mathrm{CS}+\Delta \mathrm{PS}=\mathrm{P}_{0} \mathrm{Q}_{0} \mathrm{~K}(1+0.5 \mathrm{Z} \eta)$

(Alston et al., 1988, 1998, 2000).

Where,

$K$ : is the vertical shift of supply function expressed as a proportion of the initial price, $h$ is the absolute value of the elasticity of demand

$Z=K e /(e+h)$ is the reduction in price, relative to its initial (i.e. pre-research) value, due to the supply shift.

$e \quad$ is the elasticity of supply.

$\triangle C S$ is change in consumer surplus.

$\triangle P S$ is change in producer surplus.

$\triangle T S$ is change in total surplus.

In addition, propensity score matching technique was utilised to assess the overall impact of advanced technology on the yield and income of the growers.

\section{B. Propensity score matching}

A propensity score is a single summary score that represents the relationship between multiple observed characteristics for group members and treatment group assignment. It has been described as "propensity towards exposure to treatment given the observed covariates" (Rosenbaum \& Rubin, 1983). Propensity score considers simultaneously all the relevant characteristics and attempts to reduce selection bias by weighing the characteristics relative to their influence on predicting treatment group assignment (Rudner \& Peyton, 2006). The idea underlying propensity score matching is that if a member of the treatment group is matched with a member of the control group, both have the same probability of being in the treatment condition (i.e., the same assumption underlying random group assignment designs) (Henderson \& Chatfield, 2011). In observational studies there are often significant difference between characteristics of a treatment group and a controlled group (Essama-Nssah, 2006). Such differences should not exist in randomized trial. These differences must be adjusted in order to 
reduce treatment selection bias and to determine treatment effect. To reduce these bias different matching methods were used. The goal of randomization is to balance treatment groups on any confounding factors (whether observed or unobserved), eliminating treatment selection bias and ensuring that the groups are comparable (Morgan, 2017). Propensity Score for $i^{\text {th }}$ respondent may be symbolically represented as:

$e_{i}=\operatorname{Pr}\left(Z_{i}=1 \mid X_{i}\right)$ (Rosenbaum \& Rubin, 1983)

Where $Z_{i}$ is indicator variable for application or non-application of treatment (0 or 1 respectively). Propensity Scores are generally estimated using a logistic regression model, which in this study, is Probit Regression.

The Average Impact of the Treatment on Treated (ATT) can be estimated, which is defined as the average effect of treatment on those respondents who ultimately received the treatment. ATT could be represented as:

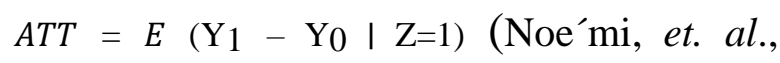
2014)

ATT was estimated by using four algorithms i.e. Nearest Neighbor Matching (NNM), Kernel Matching Stratified Matching and Radius Matching (Imbens \& Angrist, 1994)

\section{Results \& Discussion}

\section{Area and production}

The area under saffron cultivation increased, declined and again increased by $31.79,-40.50$ and 30.38 per cent from TE-I to TE-II ,TE-II to TE-III and TE-III to TE-IV, respectively, against the production registering 31.03, $45.61,114.03$ per cent and yield recording 2.97, 7.39 and 64.31 per cent change respectively, during the period under discussion. Due to increase in both area and yield during the last decade, the production has also witnessed an increase of 7.07 M.T. The figures of estimated CGR in area, production and yield for three decades, registered in the table (1) demonstrated a significant and positive growth of 3.28, 11.18 and 7.73 per cent respectively, during the decade gone (2003-13) which is a very positive outcome of the advanced production module of saffron developed by SKUAST-K. The adoption of new technology (NIAP production module system) has changed the dynamics of crop economics (Jones et al., 2009). It has led to changes in input use pattern and labour use. Due to the adoption of new technology the yield of saffron and corms has increased which resulted in the increase in gross and net returns up by 215

Table (1): Triennium wise area, production and yield and decadal growth (CGR) of Saffron in J and $\mathrm{K}$.

\begin{tabular}{|c|c|c|c|}
\hline Year & Area (ha) & Production (M.T.) & Yield $\left(\mathrm{Kg}^{-h^{-1}}\right)$ \\
\hline TE-I & 3702 & 8.70 & 2.37 \\
\hline TE-II & 4879 & 11.40 & 2.30 \\
\hline TE-III & 2903 & 6.20 & 2.13 \\
\hline TE-IV & 3785 & 13.27 & 3.50 \\
\hline \multicolumn{4}{|c|}{ Annual Compound growth rate } \\
\hline $1983-93$ & 2.21 & 2.03 & 0.00 \\
\hline $1993-03$ & -5.05 & -5.30 & -0.42 \\
\hline $2003-13$ & 3.28 & 11.18 & 7.73 \\
\hline
\end{tabular}


per cent and 472.3 per cent in ex-ante study and 151.6 per cent and 337.3 per cent in ex-post study respectively which intern resulted in increase in marketable surplus substantially.

The cost of cultivation recorded an increase of 13.6 per cent and 5.9 per cent under ex-ante and ex-post studies respectively. The potential of the improved technology could be judged by the fact that its use increased the returns per rupee invested by around 172.2 and 133.3 per cent under ex-ante and ex-post studies respectively. The other social and economic gains were the increase in employment by 40.6 per cent and 28.3 per cent and the domestic consumption by 67.4 per cent under ex-ante and ex-post studies respectively. The overall analysis depicts that due to the adoption of new technology, the socioeconomic status of the people (adopters) has increased significantly (Tables 2 and 3 ).

\section{Partial Budget Estimates}

Partial budgeting technique was utilised to assess the impact of improved technology in terms of net economic benefits (Chen \& Ravallion, 2003). The results reveal that new technology requires more costs on human/physical labour and inputs in the form of corms accounting for Rs $79522 \mathrm{ha}^{-1}$ and Rs 84892 ha $^{-1}$ under ex-ante and ex-post studies respectively. However, the credit side shows that considerable gains has been acquired by the adopters in the form of boost in saffron yield to the tune of $2.34 \mathrm{~kg} \cdot \mathrm{ha}^{-1}$ and $3.48 \mathrm{~kg} \cdot \mathrm{ha}^{-1}$ and corm yield increased by 6 q.ha- ${ }^{-1}$ respectively under ex-ante and expost studies respectively amounting to the total credit of 401458 Rs.ha $^{-1}$ and 543787 Rs.ha ${ }^{-1}$ respectively.

The net change in returns led to an increased amount of 321936 Rs.ha ${ }^{-1}$ and 458895 Rs.ha $^{-1}$ under ex-ante and ex-post studies respectively. From the analysis of tables $(4 \& 5)$ it could be conclude that the adoption of new technology has substantially enhanced the living conditions of the people by generating signifying the quantum of the social gain accrued to the community through adoption of new technology.

Table (2): Impact of improved production system module on saffron growers (Ex-Ante). Impact of new technology on saffron growers.

\begin{tabular}{|c|c|c|c|}
\hline Particulars & Non-adopter & Adopter & (\%) Change \\
\hline Saffron Yield $\left(\mathrm{kg} \cdot \mathrm{ha}^{-1}\right)$ & 2.57 & 6.05 & 135.4 \\
\hline Corms yield $\left(\mathrm{q} \cdot \mathrm{ha}^{-1}\right)$ & 9 & 15 & 66.7 \\
\hline Gross returns $\left(\right.$ Rs.ha $\left.^{-1}\right)$ & 275591 & 868000 & 215.0 \\
\hline Cost of cultivation $\left(\mathrm{Rs} \mathrm{ha}^{-1}\right)$ & 154600 & 175600 & 13.6 \\
\hline Net returns $\left(\mathrm{Rs} \mathrm{ha}^{-1}\right)$ & 120991 & 692400 & 472.3 \\
\hline Cost of production (Rs. $\left.\mathrm{kg}^{-1}\right)$ & 60155 & 29024 & -51.8 \\
\hline Returns per rupee invested (Rs.ha $\left.{ }^{-1}\right)$ & 1.8 & 4.9 & 172.2 \\
\hline Marketable surplus (kg.ha $\left.{ }^{-1}\right)$ & 2.53 & 5.98 & 136.4 \\
\hline Employment (human- days.ha ${ }^{-1}$ ) & 219 & 308 & 40.6 \\
\hline Domestic consumption $\left(\mathrm{kg} \cdot \mathrm{ha}^{-1}\right)$ & 0.043 & 0.072 & 67.4 \\
\hline
\end{tabular}


Wani et al., / Basrah J. Agric. Sci., 34(2): 118-132, 2021

Table (3): Impact of improved production system module on saffron growers (Ex-post).

\begin{tabular}{|c|c|c|c|}
\hline Particulars & Non-adopter & Adopter & (\%) Change \\
\hline \multicolumn{4}{|c|}{$\begin{array}{l}\text { Saffron Yield }\left(\mathrm{Kg}^{\mathrm{h}} \mathrm{ha}^{-1}\right) \\
\text { Main Product }\end{array}$} \\
\hline Stigmas & 2.57 & 4.91 & 91.1 \\
\hline \multicolumn{4}{|c|}{ By Product } \\
\hline Stamens & 2.45 & 4.83 & 97.1 \\
\hline Petals & 23.4 & 35.7 & 52.6 \\
\hline Corms yield (q.ha $\left.{ }^{-1}\right)$ & 9 & 15 & 66.7 \\
\hline Gross returns $\left(\right.$ Rs.ha $\left.^{-1}\right)$ & 275591 & 693320 & 151.6 \\
\hline Cost of cultivation $\left(\right.$ Rs.ha $\left.^{-1}\right)$ & 154600 & 163722 & 5.9 \\
\hline Net returns $\left(\right.$ Rs.ha $\left.^{-1}\right)$ & 120991 & 529598 & 337.7 \\
\hline Cost of production $\left(\mathrm{Rs} \cdot \mathrm{kg}^{-1}\right)$ & 60155 & 33345 & -44.6 \\
\hline Returns per rupee invest ted $\left(\right.$ Rs.ha $\left.^{-1}\right)$ & 1.8 & 4.2 & 133.3 \\
\hline Marketable surplus $\left(\mathrm{kg} \cdot \mathrm{ha}^{-1}\right)$ & 2.53 & 4.84 & 91.3 \\
\hline Employment (human- days.ha ${ }^{-1}$ ) & 219 & 281 & 28.3 \\
\hline Domestic consumption $\left(\mathrm{kg} \cdot \mathrm{ha}^{-1}\right)$ & 0.043 & 0.072 & 67.4 \\
\hline
\end{tabular}

Table (4): Ex-Ante (Partial Budgeting).

\begin{tabular}{|c|c|c|c|}
\hline \multicolumn{2}{|l|}{ Debit } & \multicolumn{2}{|l|}{ Credit } \\
\hline Particulars & $\begin{array}{l}\text { Amount } \\
\left(\text { Rs.ha }^{-1}\right)\end{array}$ & Particulars & $\begin{array}{l}\text { Amount } \\
\left(\text { Rs.ha }^{-1}\right)\end{array}$ \\
\hline $\begin{array}{l}\text { Increase in cost per hectare } \\
\text { Corms 3q @ Rs } 13464\end{array}$ & 40392 & $\begin{array}{c}\text { Increase in income per hectare } \\
\text { Main product (Stigmas) } \\
\text { Saffron yield } 3.48 \mathrm{~kg} / \mathrm{ha}^{-1} @ \mathrm{Rs} \\
132145\end{array}$ & 459865 \\
\hline $\begin{array}{l}\text { Human labour } 89 \text { man days @ Rs } \\
500 \text { per day }\end{array}$ & 44500 & Corms yield 6 q/ha-1 @ Rs 13464 & 83922 \\
\hline Decrease in income per hectare & 0.00 & Decrease in cost per hectare & 0.00 \\
\hline Total $\left(\right.$ Rs. ha $\left.{ }^{-1}\right)$ & 84892 & & 543787 \\
\hline \multicolumn{2}{|c|}{ Net change $\left(\right.$ Rs. ha $\left.{ }^{-1}\right)$} & 458895 & \\
\hline
\end{tabular}

Table (5): Ex-Post (Partial Budgeting).

\begin{tabular}{|c|c|c|c|}
\hline \multicolumn{2}{|c|}{ Debit } & \multicolumn{2}{c|}{ Credit } \\
\hline Particulars & $\begin{array}{c}\text { Amount } \\
\left(\text { Rs.ha }^{-1}\right)\end{array}$ & Particulars & $\begin{array}{c}\text { Amount } \\
\left(\mathrm{Rs.ha}^{-1}\right)\end{array}$ \\
\hline $\begin{array}{c}\text { Increase in cost per hectare } \\
\text { Inputs (Corms) } \\
\begin{array}{c}\text { Increase in corm use 3.54 } \\
\text { q/ha @ Rs 13987 }\end{array}\end{array}$ & 49514 & $\begin{array}{c}\text { Increase in income per hectare } \\
\text { Main product (Stigmas) } \\
\text { Increase in saffron yield 2.34 } \\
\mathrm{kg} / \mathrm{ha}^{-1} @ \text { Rs 132145 }\end{array}$ & 306163 \\
& & & \\
\hline
\end{tabular}


Wani et al., / Basrah J. Agric. Sci., 34(2): 118-132, 2021

\begin{tabular}{|c|c|c|c|}
\hline $\begin{array}{c}\text { Inputs (Labour) } \\
\text { Increase in human labour } 62 \\
\text { man days @ Rs } 484 \text { per day }\end{array}$ & 30008 & $\begin{array}{c}\text { By product (Corms) } \\
\text { Increase in corm yield } 6 \text { q/ha }{ }^{-1} \\
\text { @ Rs } 13987\end{array}$ & 83958 \\
\hline & & $\begin{array}{c}\text { By product (Stamens) } \\
\text { Increase in stamens yield (by } \\
\text { product) } 1.79 \mathrm{~kg} \cdot \mathrm{ha}^{-1} @ \mathrm{Rs} 4003\end{array}$ & 7045 \\
\hline & & $\begin{array}{c}\text { By product (Petals) } \\
\text { Increase in petals yield (by } \\
\text { product) } 14.5 \mathrm{~kg} \cdot \mathrm{ha}^{-1} @ \text { Rs } 296\end{array}$ & 4292 \\
\hline $\begin{array}{l}\text { Decrease in income per } \\
\text { hectare }\end{array}$ & 0.00 & Decrease in cost per hectare & 0.00 \\
\hline Total $\left(\mathrm{Rs} \mathrm{ha}^{-1}\right)$ & 79522 & & 401458 \\
\hline \multicolumn{2}{|c|}{ Net change $\left(\mathrm{Rs} \mathrm{ha}^{-1}\right)$} & \multicolumn{2}{|l|}{321936} \\
\hline
\end{tabular}

Note: $*$ Price differential $=$ Price after technology - price before technology

\section{Aggregate benefits}

Economic surplus model estimates are presented in tables $(6 \& 7)$. The price elasticities of demand and supply of saffron were estimated through functional analysis employed on secondary and primary information collected on prices from the producers and consumers (from various income groups) pertaining to various periods of time in a year. The estimates of demand and supply elasticity thus obtained were 0.31 and 0.21 respectively under both ex-ante and ex-post studies. The analysis showed a significant improvement in yield level in the study area on adoption of new technology. Estimates of ESM revealed NPV of Rs. 398 crores, IRR (154\%) and BCR of 110 under ex-ante compared to NPV of Rs. 249 crores, IRR (134\%) and BCR of 69 under ex-post evaluation signifying the quantum of the social gain accrued to the community through adoption of new technology.

\section{Technological gaps}

Technological gap is the difference between the potential technologies that can be applied compared to the actual amount of technology being applied (Alonge Adewale Johnson, 1993; Sahu \& Das, 2015). Thus in case of adoption of production system module in saffron, high technological gaps ranging from 15.6 per cent to 50 per cent were estimated under three very essential components of the production system like corm (16.6\%), potassium (15.6\%) and the highest of 50 per cent in organic fertilizer. It could therefore be construed that the presence of a higher yield gap between existing and recommended level of technology could be reduced if the production system module developed by SKUAST-K in saffron is adopted in full by the growers. 
Table (6): Returns from investment on new technology revealed through Estimates of Economic Surplus Model (Ex-ante).

\begin{tabular}{|l|c|}
\hline \multicolumn{1}{|c|}{ Particulars } & Values \\
\hline Yield change/ha $^{-1}$ & 3.48 \\
\hline Variable cost change/unit of output & 1.36 \\
\hline Target area (\%) to be covered in 2020 & 75 \\
\hline Time to achieve maximum adoption & $2014-2020$ \\
\hline Elasticity of supply & 0.21 \\
\hline Elasticity of demand & 0.31 \\
\hline Annual growth in area (\%) during 1983-2013 & 0.08 \\
\hline Prob. Success & 1 \\
\hline NPV(cr.) & 399 \\
\hline IRR (\%) & 154 \\
\hline BC Ratio & 110 \\
\hline
\end{tabular}

Table (7): Returns from investment on new technology revealed through Estimates of Economic Surplus Model (Ex-post).

\begin{tabular}{|l|c|}
\hline \multicolumn{1}{|c|}{ Particulars } & Values \\
\hline Yield change Kg.ha $^{-1}$ & 2.34 \\
\hline Variable cost change per ha $^{-1}$ & 1.47 \\
\hline Target area to be covered in 2020 & 70 \\
\hline Time to achieve maximum adoption & $2014-2020$ \\
\hline Elasticity of supply & 0.21 \\
\hline Elasticity of demand & 0.31 \\
\hline Prob. Success & 0.7 \\
\hline NPV(cr) & 249 \\
\hline IRR $(\%)$ & 134 \\
\hline BC Ratio & 69 \\
\hline
\end{tabular}

\section{Propensity score matching}

A propensity score is a single summary score that represents the relationship between multiple observed characteristics for group members and treatment group assignment. It has been described as "propensity towards exposure to treatment given the observed covariates" (Rosenbaum \& Rubin, 1983; Westreich et al., 2010) Propensity score considers simultaneously all the relevant characteristics and attempts to reduce selection bias by weighing the characteristics relative to their influence on predicting treatment group assignment (Rudner \& Peyton, 2006). The idea underlying propensity score matching is that if a member of the treatment group is matched with a member of the control group, both have the same probability of being in the treatment condition (i.e., the same assumption 
underlying random group assignment designs). In observational studies there are often significant difference between characteristics of a treatment group and a controlled group. Such differences should not exist in randomized trial. These differences must be adjusted in order to reduce treatment selection bias and to determine treatment effect (Table 8).
In this study the total number of 447 respondents was taken for analytical purpose. Out of total 286 were non-treated (controlled group) and 161 were treated. Table (9), it becomes evident that out of 286 non-treated respondents; 45, 161, 78, and 2 and out of 161 treated respondents: 8, 89, 61 and 3 fall in the p-score (propensity score) $0.1,0.2,0.4$ and 0.6 respectively.

Table (8): Extent of technological gaps on improved production system module in saffron (Ex-post).

\begin{tabular}{|c|c|c|c|c|c|c|}
\hline $\begin{array}{c}\text { Adoption of } \\
\text { technology }\end{array}$ & Corm & N & P & K & FYM & Organic fertilizer \\
\hline Before & -77.7 & -92.3 & -89.4 & -86.7 & -10.2 & -94.8 \\
\hline After & -16.6 & 31.1 & 8.3 & -15.6 & 34 & -50 \\
\hline
\end{tabular}

Table (9): Inferior bound, number of treated and the number of controls for each block.

\begin{tabular}{|c|c|c|c|}
\hline Inferior of block of pscore & Untreated (0) & Treated (1) & Total \\
\hline 0.1 & 45 & 8 & 53 \\
\hline 0.2 & 161 & 89 & 250 \\
\hline 0.4 & 78 & 61 & 139 \\
\hline 0.6 & 2 & 3 & 5 \\
\hline Total & 286 & 161 & 447 \\
\hline
\end{tabular}

For estimating propensity score from any distribution few steps are involved to complete the total procedure, firstly, the overall propensity score of the whole distribution needs to be estimated, secondly, the data in the distribution needs to be matched on the basis of estimated propensity score Third, the whole balancing property of the group must be satisfied in order to ensure the proper matching among control and treated groups. Fourth, and the final step involved in propensity score matching is that it can be analysed to estimate average treatment (ATT) effect.

The analysis of table (10) after regression of income with the treatment and the controlled variables, the average income of the farmers in the distribution turned out to be Rs. 340156.9/- with a standard error of
14051.71 having a t-value 24.21 at $5 \%$ level of significance against the income of control group of Rs. 144690/- with a standard error of 8172.195 and a t-value 17.71 at $5 \%$ level of significance.

Table (11) shows the average treatment effect on treated with different matching methods. The four different matching methods employ different procedures for getting the proper match among the distribution, the nearest neighbour method or nn' match method shows that in the total observation number of treated observation were 161 and it could only find 120 control variables whole propensity score has been matched with an ATT of 3.56, standard error 19226.196 and a t-value 18.502 meaning 
thereby that there a significant impact at 5 per cent level of significance (Kurth, et al., 2006).

The Kernel, radius and stratification matching methods, took 161 treated observations with 286 control observation each for mating and there ATT, standard error and t-value comes out as 3.32, 3.36 and 3.28, 16261.87, 15242.326 and 17225.349 and $20.392,22.063$ and 19.00 respectively at $5 \%$ level of significance.

Table (10): Regression of income with the treatment group.

\begin{tabular}{|c|c|c|c|c|cc|}
\hline Y & Coef. & Std. Err. & T & $\mathbf{P}>|\mathbf{t}|$ & \multicolumn{2}{|c|}{ [95\% Conf. Interval } \\
\hline Trt & 340156.94 & 14051.71 & 24.21 & 0.000 & 312545.5 & 367768.3 \\
\hline cons & 144690 & 8172.195 & 17.71 & 0.000 & 128631.8 & 160748.2 \\
\hline
\end{tabular}

Table (11): Average treatment of treated with different matching methods.

\begin{tabular}{|c|c|c|c|c|c|}
\hline Matching Methods & n. treat & n. contr. & ATT & Std. Err. & T \\
\hline $\begin{array}{c}\text { ATT estimation with Nearest } \\
\text { Neighbour Matching Method } \\
\text { (attnd) }\end{array}$ & 161 & 120 & $3.56 \mathrm{e}+05$ & 19226.196 & 18.502 \\
\hline $\begin{array}{c}\text { ATT estimation with Kernel } \\
\text { Matching Method (attk) }\end{array}$ & 161 & 286 & $3.32 \mathrm{e}+05$ & 16261.876 & 20.392 \\
\hline $\begin{array}{c}\text { ATT estimation with Radius } \\
\text { Matching Method (attr) }\end{array}$ & 161 & 286 & $3.36 \mathrm{e}+05$ & 15242.326 & 22.063 \\
\hline $\begin{array}{c}\text { ATT estimation with } \\
\text { Stratification Matching Method } \\
\text { (atts) }\end{array}$ & 161 & 286 & $3.28 \mathrm{e}+05$ & 17225.349 & 19.00 \\
\hline
\end{tabular}

Table (12) shows the average treatment effect on treated (ATT) calculated from different matching methods employed to the set of observations (Blundell \& Costa-Dias, 2000; Ho et al., 2011). The ATT estimated from nearest neighbour method by doing 100 replications to the data set comes out to be Rs. 355727.8/- with a bias of -5979.628 and standard error of 15843.56 at $5 \%$ level of significance, indicating that by using advanced production system module farmers increased their income by Rs.355727.8. Similarly, the average treatment effect of treated (ATT) estimated through kernel matching method, radius matching method and stratification matching method by doing 100 replications each realizing a gain of Rs.
$331619.3 /-, 336284.4,327965.2$ with a bias of $2401.869,-1006.632,2787.328$ and a standard error of 16261.87, 151163.9 and 117225.35 at $5 \%$ level of significance respectively revealing that farmers increased their income by Rs.17225.35, 336284.4 and 327965.2 respectively by using advanced production system module.

\section{Propensity Score Graph (ps-graph)}

The propensity score matching graph was used to explain the number of treated and untreated observations that got support and those which did not get support in the distribution (Dehejia \& Wahba, 2002). Ps graph demonstrated the treated cases in green on top, the controlled cases in brown at bottom and the blue bars show the untreated cases devoid of the support. 
Table (12): Showing estimation of average treatment effect on treated (ATT) using different matching methods.

\begin{tabular}{|c|c|c|c|c|ccc|}
\hline Variable & Reps & Observed & Bias & Std. Err. & \multicolumn{4}{|c|}{ [95\% Conf. Interval] } \\
\hline Attnd & 100 & 355727.8 & -5979.628 & 15843.56 & 324290.7 & 387164.8 & $(\mathrm{~N})$ \\
& & & & & 323426.6 & 376936.1 & $(\mathrm{P})$ \\
\hline Attk & 100 & 331619.3 & 2401.869 & 16261.87 & 299352.2 & 299352.2 & $(\mathrm{~N})$ \\
& & & & & 308295.6 & 376920.3 & $(\mathrm{P})$ \\
& & & & & 308295.6 & 376920.3 & $(\mathrm{BC})$ \\
\hline Attr & 100 & 336284.4 & -1006.632 & 151163.91 & 306195.9 & 366372.9 & $(\mathrm{~N})$ \\
& & & & & 307478.9 & 362641.3 & $(\mathrm{P})$ \\
& & & & & 308352.7 & 364066.5 & $(\mathrm{BC})$ \\
\hline Atts & 100 & 327965.2 & 2787.328 & 17225.35 & 293786.4 & 362144 & $(\mathrm{~N})$ \\
& & & & & 299254.6 & 362676.2 & $(\mathrm{P})$ \\
& & & & & 295842.1 & 360398.9 & $(\mathrm{BC})$ \\
\hline
\end{tabular}

Note: $\mathbf{N}=$ normal, $\mathbf{P}=$ percentile and $\mathrm{BC}=$ bias corrected

The fig. (1) looks promising, because, almost all the controlled and uncontrolled cases had propensity score ranging from 0.1 to 0.6 and there seems to be lesser cases having propensity score greater than 0.6. Similarly some of the case were found without any support in the distribution, likewise some cases in the treatment group found no support in the controlled group.

\section{Kernel density}

Estimating the density with a histogram is easy but it is not smooth enough to have a fairly good picture of the distribution. In order to get a smoother picture kernel density method is employed. In kernel density the data are divided into non-overlapping intervals, and counts area made of the number of data points within each interval. In more general kernel density estimates, the range is still divided into intervals, and estimates of the density are produced at the centre of intervals. From the fig. (2), it can be seen that the density ranges from 0 to 4 as is shown along the $y$-axis and the scale of propensity is shown along $\mathrm{x}$-axis. The area under the brown line (non-adopters) whose propensity ranges from 0.1 to 0.7 and the majority of the adopters (grey line) also fall in that range, that means almost 70 to 80 per cent of the adopters are falling within the range and find their common support in the data set while as few of the observations did not find their support in the data set 
Wani et al., / Basrah J. Agric. Sci., 34(2): 118-132, 2021

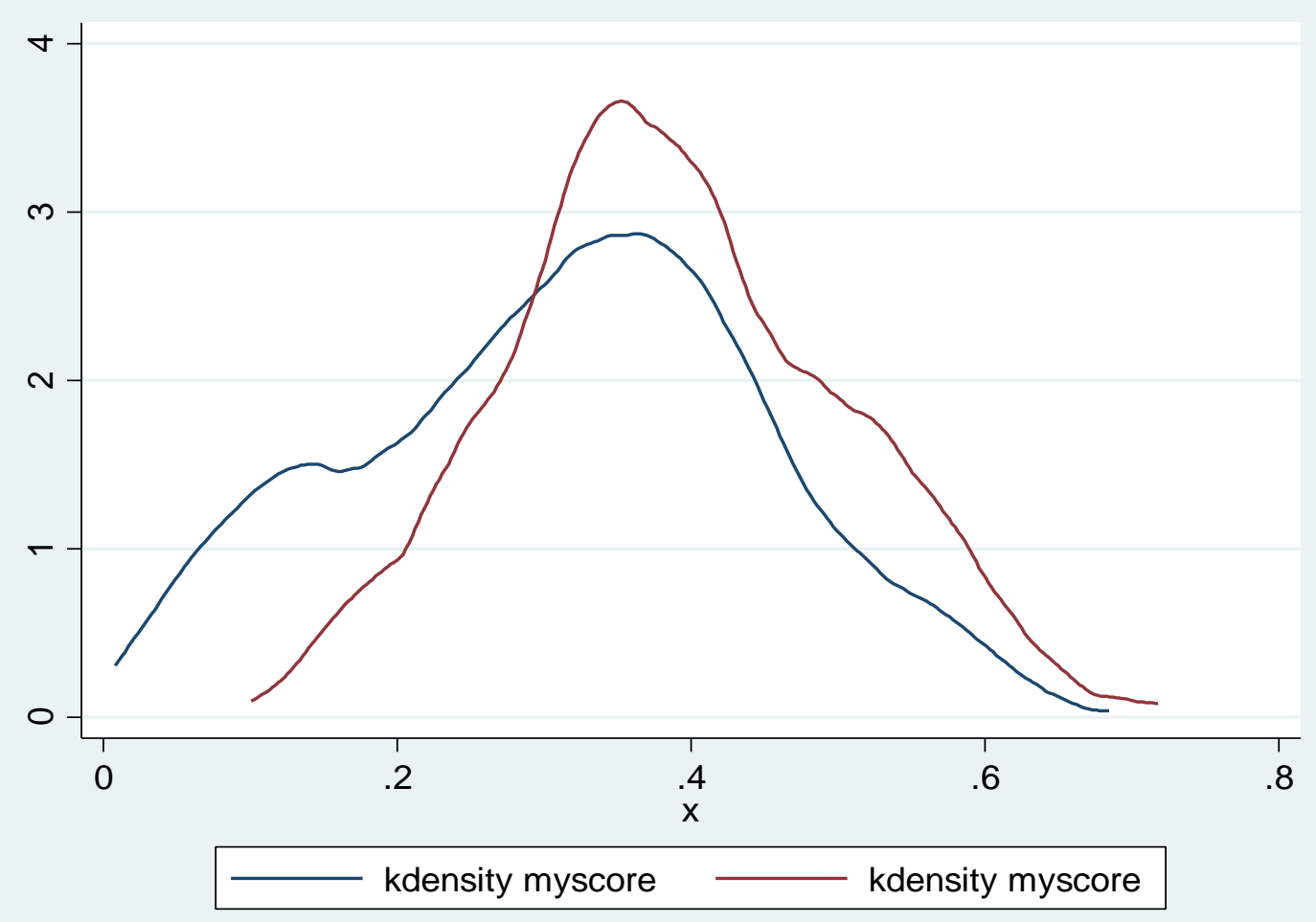

Fig. (1): Propensity score matching graph.

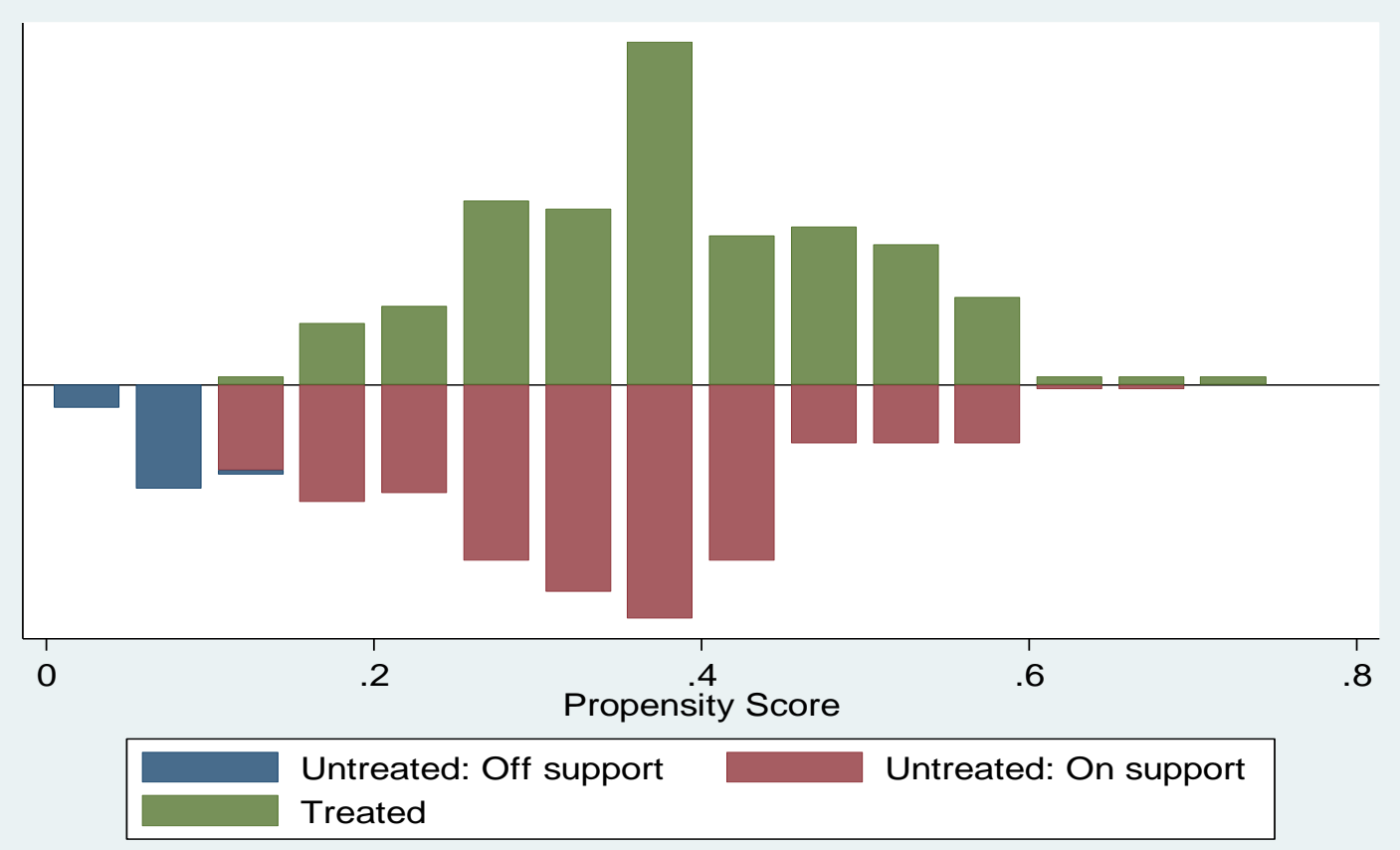

Fig. (2): Two way kernel density graph. 


\section{Conclusions}

The study concludes that average productivity of saffron increased from $2.57 \mathrm{~kg} \cdot \mathrm{ha}^{-1}$ to 6.05 $\mathrm{kg} \cdot \mathrm{ha}^{-1}$, with 1-2 kg.ha ${ }^{-1}$ in the first year to 10 $12 \mathrm{~kg} \cdot \mathrm{ha}^{-1}$ in fourth year against non-adopters. The higher investment cost of $5.9 \%$ and $13.6 \%$ under ex-ante and ex-post evaluation got compensated through realizing higher productivity and increased employment. The realization of NPV, BCR and IRR of Rs. 399 crores, 110 and $154 \%$ against Rs. 249 crores, 69 and $134 \%$ respectively under ex-ante and ex-post evaluation of the technology was considered very encouraging towards increasing the living standard of the people in the area. The estimates of the propensity score matching too confirmed the results of increasing the wellbeing and living standard of the general public in the saffron growing region. The results suggest that the postharvest handling of saffron is an important area involved in its production and marketing demanding establishment of processing units and labs for its post-harvest handling especially drying and packing. The study further suggests that policies need to be evolved by the Government of India towards its efficient grading, branding and labelling which were observed to be important determinants of its trade and are expected to help in competing in the international market.

\section{Acknowledgements}

We extend our sincere thanks to University Grants Commission and ICAR for providing us financial support. Thanks are equally due to Vice-chancellor (Prof. Nazeer Ahmed), SKUAST-K for providing valuable suggestions in completing this study in wonderful manner.

\section{Orcids}

M. H. Wani: https://orcid.org/0000-00020165-8555

Arshad Bhat: https://orcid.org/0000-00029689-2351

S. H. Baba: https://orcid.org/0000-0002-04505116

\section{References}

Adewale A. J., (1993). An assessment of the impact of Farming Systems Research/Extension on the adoption of agricultural technologies in the MiddleBelt region of Nigeria, Retrospective Theses and Dissertations. 10399.

Alston, J. M., Craig, B. J., \& Pardey, P. G. (1998). Dynamics in the creation and depreciation of knowledge, and the returns to research. Discuss. Pap. 35, EPTD, International Food Policy Research Institute.

https://core.ac.uk/download/pdf/194595032.pdf

Alston J. M., Edwards G. W, Freebairn J. W., (1988). Market distortions and the benefits from research. American Journal of Agricultural Economics, 70, 281-288.

https://ideas.repec.org/a/oup/ajagec/v70y1988i2p28 1-288..html

Alston, J. M., Chan-Kang, C., Marra, M. C., Pardey, P. G., \& Wyatt, T. J. (2000). A meta-analysis of rates of return to agricultural $R$ and $D$. IFPRI research report no. 113. International Food Policy Research Institute: Washington, D. C. https://www.ifpri.org/publication/meta-analysisrates-return-agricultural-r-d

Blundell, R., \& Costa-Dias, M. (2000). Evaluation methods for non-experimental data. Fiscal Studies, 21 , 427-468. https://econpapers.repec.org/article/ifsfistud/v_3a2 1_3ay_3a2000_3ai_3a4_3ap_3a427-468.htm

Morgan, C. J. (2017). Reducing bias using propensity score matching, Journal of Nuclear Cardiology, 25, 404-406 https://doi.org/10.1007/s12350-017-1012$\mathrm{y}$

Chen, S., \& Ravallion, M. (2003). Hidden impact? Expost evaluation of an anti-poverty program. World Bank Policy Research Working Paper No. 3049. https://doi.org/10.1596/1813-9450-3049 


\section{Wani et al., / Basrah J. Agric. Sci., 34(2): 118-132, 2021}

Dehejia, R. H., \& Wahba, S. (2002). Propensity scorematching methods for non-experimental causal studies. The Review of Economics and Statistics, 84 , 151-161. https://econpapers.repec.org/article/tprrestat/v_3a8 4_3ay_3a2002_3ai_3a1_3ap_3a151-161.htm

Economic Survey, (2019). Directorate of Economics and Statistics, Government of Jammu and Kashmir. http://www.ecostatjk.nic.in/JKINDIANECO/2018. pdf.

Essama-Nssah, B. (2006). Poverty Reduction Group (PRMPR). The World Bank Washington, D. C. WPS: $3877 \mathrm{pp}$. https://openknowledge.worldbank.org/bitstream/ha ndle/10986/8730/wps38770rev0pdf.pdf.

Ho, D. E., Imai, K., King, G., \& Stuart, E. A. (2011). Match It: Nonparametric preprocessing for parametric causal inference. Journal of Statistical Software,

42 , https://www.jstatsoft.org/article/view/v042i08

Imbens, G. W., \& Angrist, J. D. (1994). Identification and estimation of local average treatment effects. Econometrica, 62, 467-475. https://www.jstor.org/stable/2951620?seq=1

Henderson, J., \& Chatfield, S. (2011). Who matches? Propensity score and bias in the causal effects of education on participation. The Journal of Politics, 73 , 646-658. https://doi.org/10.1017/S0022381611000351

Jones, N., Jones, H., Steer, L., \& Datta, A. (2009). Improving Impact Evaluation, Production and Use. (ODI: Working Paper), 78pp. http://www.odi.org.uk/resources/docs/4158.pdf

Khalid, S. (2018). Decline in saffron production and its impact on state economy, Kashmir Images, https://thekashmirimages.com/2018/08/30/declinein-saffron-production-its-impact-on-state-economy/

Kurth, T., Walker, A. M., Glynn, R. J., Chan, K. A., Gaziano, J. M., \& Berger, K. (2006). Results of multivariable logistic regression, propensity matching, propensity adjustment, and propensitybased weighting under conditions of non-uniform effect. American Journal of Epidemiology, 163, 262-270. https://doi.org/10.1093/aje/kwj047

Nehvi, F. A., Dhar, J. K., Sheikh, S. S., Iqbal, A. M., \& John, A. A. (2018). Conventional postharvest practices and their impact on saffron quality-a study Acta Horticulturae1200. ISHS 2018. https://doi.org/10.17660/ActaHortic.2018.1200.23 Proceeding IV International Symposium on Saffron Biology and Technology, Nehvi, F. A., \& Wani, S. A. (Editors).

Noe'mi, K., Gruber, S., Radice, R., Grieve, R., \& Jasjeet, S. S. (2014). Evaluating treatment effectiveness under model misspecification: A comparison of targeted maximum likelihood estimation with bias-corrected matching, Statistical Methods in Medical Research, 25, 2315-2336 https://doi.org/10.1177\%2F0962280214521341

Rosenbaum, P. R., \& Rubin, D. B., (1983). The Central Role of the Propensity Score in Observational Studies for Causal Effects. Biometrika, 70, 4155, https://doi.org/10.1093/biomet/70.1.41.

Rudner, L. M., \& Peyton, J. (2006). Consider propensity score to compare treatments. Practical Assessment, Research and Evaluation, 11, 19.https://scholarworks.umass.edu/cgi/viewcontent.c gi article $=1195 \&$ context $=$ pare

Sahu, S., K., \& Das, S. (2015). Impact of agricultural related technology adoption on poverty: A study of selected households in rural India, Working Paper 131/2015, Madras School of Economics, Gandhi Mandapam Road Chennai 600 025, India, 25pp. http://admin.indiaenvironmentportal.org.in/files/file /Impact\%20of\%20Agricultural\%20Related\%20Tec hnology.pdf

UNIDO. (2014). Saffron Industry Value Chain Development In Iran, Diagnostic Study Report United Nations Industrial Development Organization Vienna International Centre, P.O. Box 300, 1400 Vienna, Austria, https://open.unido.org/api/documents/4672742/dow nload/Saffron $\% 20$ Industry $\% 20$ Value $\% 20$ Chain $\% 2$ 0Development\%20In\%20Iran\%20$\% 20$ Diagnostic\%20Study\%20Report

Westreich, D., Lessler, J., \& Funk, M. J. (2010). Propensity score estimation: machine learning and classification methods as alternatives

to logistic regression. Journal of Clinical Epidemiology, 63, 826-833. https://dx.doi.org/10.1016\%2Fj.jclinepi.2009.11.02 0 


\title{
التقييم السابق واللاحق لنظام الإنتاج المتقدم لنات الزعفران Crocus sativus في الهند باستخدام نموذج فائض المستهلك ومطابقة درجة الميل
}

\author{
1مسدول واني1 و ارشد بهات1 وساجد باب2 \\ 1 رئيس قسم الدر اسات المعاصرة وسبل العيش و الامن الغذائي جامعة شير - ايـ كثمير للعلوم و التكنولوجيا الزر اعية$$
\text { كثمير - الهند }
$$$$
\text { 2كلية الاسماك -قسم العلوم الاجتماعية- جامعة شير -اي ـكثمبر للعلوم والتكنولوجيا الزر اعية ـكثمبر ـالهند }
$$

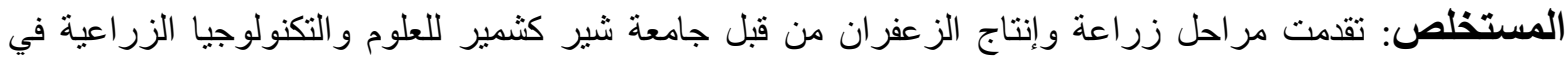

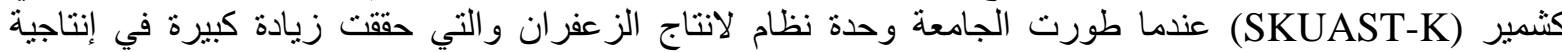

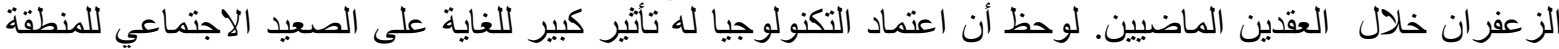

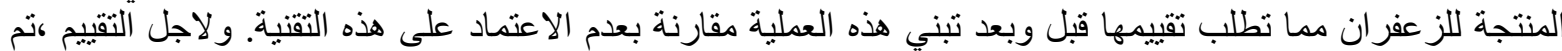

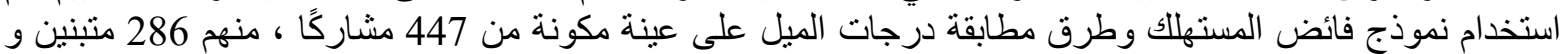

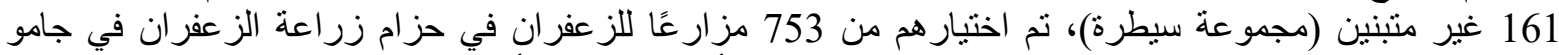

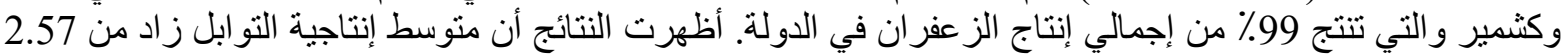

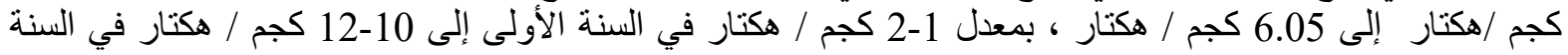

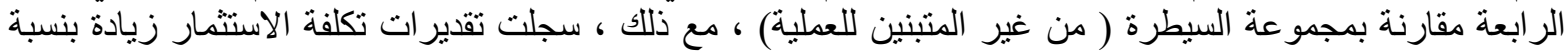

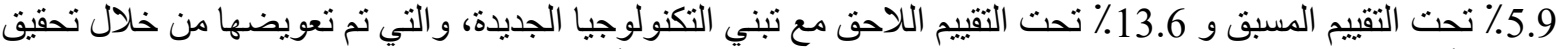
إنتاجية أعلى وزيادة التوظيف لتصل إلى 40.6 و 28.3 في المائة من أيام العمل / هكتار على التئ التي التي في إطار التقييم

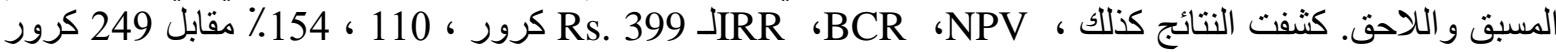
روبية ، 69 ، 134 \% على التو الي بموجب التقييم المسبق و اللاحق للتكنولوجيا. الكلمات المفتاحية: إنتاجية ، زراعة ، مستوى معيشي ، تكنولوجيا جديدة. 